\title{
The measures implemented to reduce the impact of plant protection products on pollinators in France ${ }^{\star}$
}

\author{
Fabien Lagarde* \\ Terres Inovia, 78850 Thiverval Grignon, France
}

Received 4 May 2017 - Accepted 12 July 2017

\begin{abstract}
Shortly after the introduction of systemic insecticides, new problems were observed by beekeepers on honeybee colonies. The studies carried out under laboratory conditions have shown sublethal effects on honeybee behavior. However, it was not possible to reproduce under natural conditions the effects described by beekeepers on bee colonies. In addition, studies have revealed that many other factors could also be responsible for the dysfunction of honeybee colonies. Scientists agree that problems observed on the hives are the result of multifactorial effects. Measures concerning apicultural and agricultural practices are therefore necessary to improve honeybee colonies' health and to preserve the diversity of pollinators in France.
\end{abstract}

Keywords: neonicotinoid / insecticide / flowering treatment / oilseed rape / faba

\begin{abstract}
Résumé - Les actions mises en œuvre pour réduire l'impact des produits phytopharmaceutiques sur les insectes pollinisateurs en France. Après l'introduction des insecticides systémiques, de nouveaux problèmes ont été observés par les apiculteurs sur les colonies d'abeilles. Les nombreuses études réalisées depuis pour en identifier les causes ont mis en évidence des effets sur le comportement des abeilles, sans pour autant parvenir à reproduire en conditions naturelles les effets décrits par les apiculteurs sur les colonies. Par ailleurs, les études ont montré que bien d'autres facteurs pouvaient aussi expliquer les perturbations de leur fonctionnement. Les scientifiques s'accordent pour dire qu'il s'agit d'effets multifactoriels. Des actions visant les pratiques apicoles et agricoles sont donc nécessaires pour préserver les ruches et la diversité des pollinisateurs en France (the full text is available in French on http://www.ocl-journal.org/).
\end{abstract}

Mots clés : néonicotinoïdes / insecticides / traitement en floraison / colza / féverole

\section{Historical context}

The challenges of beekeepers to farmers' practices are relatively old. As soon as deltamethrin was introduced in the late 1970 s, the molecule - and many others in the pyrethroids family that followed - due to its broad spectrum of activity and efficacy at low dose/ha compared to existing products has been the subject of animated debates between the beekeepers and the holding company.

At that time, the studies carried out within the framework of the molecule approval document concluded to an acceptable risk toward honeybees for its uses on the crops. Some concerned treatments during blooming period, such as the cabbage seedpod weevil on oilseed rape. In the 1980s, still on oilseed rape, the application of plant protection products

\footnotetext{
« The french version is available in "Supplementary Material".

*Corresponding author: $f . l$ agarde@terresinovia.fr
}

during blooming period consisted in combining a pyrethroid insecticide with the systematic fungicide protection against sclerotinia.

Again, during this period, honeybee massive losses were regularly reported by beekeepers, which incriminated these practices. Studies carried out on insecticides did not explain the phenomenon and investigations have been directed toward insecticide and fungicide association. They revealed that certain combination of products were highly toxic to bees via a synergistic effect. This work led to a better control of agricultural practices avoiding associating triazoles fungicides with pyrethroid insecticides which was a common practice at that time.

\section{The introduction of systemic seed treatments: a breakpoint for beekeepers}

At the end of the 1990s, a second wave of controversy appeared with the launch of fipronil in 1994 for maize and 
sunflower seed treatment, followed soon after by imidacloprid, a molecule belonging to the neonicotinoid insecticide family. In the previous years, the increasing of sunflower surfaces went on with the development of professional beekeeping, particularly in the central and west areas of France and honey which was majorly destined to industry usually yielded more than $50 \mathrm{~kg} /$ hive. After the introduction of these new seed treatments, beekeepers observed a decrease in sunflower honey production often between 10 and $20 \mathrm{~kg}$ per hive, jeopardizing their economic model, and attributed it to losses of bee populations in hives in particular during sunflowers blooming period.

Many hypotheses were then explored to explain the phenomena described by beekeepers. The results of the study from Henry et al. (2015), reports from Anses 2016 ${ }^{1}$ and $2017^{2}$ and their findings are still not consensus among stakeholders to date, even if the combination of multiple factors - food depletion, apicultural practices, exposure to plant protection products, in particular neonicotinoids and climatic factorsseems to be the most commonly accepted hypothesis to explain the origin of disorders described. In addition, the brutal depopulations of colonies described by beekeepers were also debated as it was very difficult to reproduce and characterize it in the experiments. Since the introduction of neonicotinoid insecticides, the challenge of beekeepers concerning their use by farmers has never stopped.

\section{Sustainable protection strategy designed at European scale}

Subsequently, the establishment in 2002 of the thematic strategy for the sustainable use of pesticides at European level, which was to define the future European framework directive concerning the sustainable use of pesticides currently in force. It was declined in France, in accordance with the guidelines set up at European level. This has resulted in the design of a specific action plan, the PIRRP ${ }^{3}$ (Interministerial plan for the reduction of risks linked to pesticides), which foreshadowed the current Ecophyto plan. For example, France-specific regulations have been introduced on mixtures prohibiting their application during flowering period with triazoles and pyrethroids, and more generally mixtures combining products having certain characteristics of dangerousness under the precautionary principle toward users such as farmers.

In addition, legislation on the protection of bees has become more stringent, with the publication of an interdepartmental decree dated 28 November $2003^{4}$ concerning the use of insecticides during periods of potential foraging activity on crops with nectar secretions or in the presence of exudates. This decree still in force to date allows treatment only for products whose use is allowed by derogation and in the absence of bees on the field during application. During the

\footnotetext{
${ }^{1}$ https://www.anses.fr/fr/system/files/SUBCHIM2015SA0142.pdf

${ }^{2} \mathrm{https}$ ://www.anses.fr/fr/content/santé-des-abeilles

${ }^{3}$ www.observatoire-pesticides.fr/upload/bibliotheque/.../pirrp_2006. pdf

${ }^{4}$ https://www.legifrance.gouv.fr/affichTexte.do?cidTexte...categorie Lien $=\mathrm{id}$
}

same period, the marketing authorization legislation (AMM) for the products was amended, with a ban on all applications of insecticides during flowering. Only derogatory applications are permitted, based on specific studies carried out by petitioners who can prove their harmlessness on bees, for treatments carried out during crop blooming in the absence of bees during their application. As a result of this change in legislation, as the authorizations were revised, farmers lost a significant number of solutions available for application during flowering. Indeed, most of the products that were authorized were not the subject of the specific studies requested because there was insufficient demand to justify them, given their cost.

\section{Plan to support the beekeeping sector associating beekeepers and farmers}

Despite all regulatory measures and positive evolutions in farmer practices, in particular the end of fungicides and insecticides applied in mixture on oilseed rape during flowering, the end of neonicotinoid seed treatments on sunflower since 1998 and more recently on maize, problems of honey production and colony losses in apiaries persisted. A plan for the sustainable development of beekeeping (MAAF, 2013) was therefore adopted by the government in February 2013. It had five main objectives:

- objectively measure the activity and health of honeybee colonies in France, leading to the establishment of an epidemiological surveillance network for colony diseases;

- to reduce the impact of pesticides on honeybee colonies, with, in particular, the immediate withdrawal of thiametoxam on oilseed rape as a seed treatment (June 2012). The introduction of a prohibition moratorium for four neonicotinoids used for seed treatment for two years (December 2013), and a complete overhaul of the insecticide assessment procedure;

- to combat diseases and predators of bees and in particular varroa, the most widespread parasite that strongly affects colonies in France and the Asian hornet, an invasive species that attacks colonies;

- making France one of the leading honey-producing countries in Europe;

- to valorize beekeeping in the service of agro-ecology.

This latter objective deals in particular with the interactions between apiculture and agriculture. In order to implement it, several measures have been decided:

- the maintenance of the "pollinisation-zones fragile" agroenvironmental measure, with support of the ITSAP action (technical institute related to bees and pollination), for the study of pollination;

- the establishment of a GIEE pollination (January 2014) in the Vendée region, involving a beekeeper and thirty-two farmers to set up a landscape management and a modification of agricultural practices in favor of pollinators (January 2014);

- actions to enhance and disseminate good agricultural practices. 
Concerning this last measure, a charter of good apicultural and agricultural practices in pollination was finalized between the ITSAP-Institut de l'abeille, ADA France ${ }^{5}$, GNIS ${ }^{6}$, $\mathrm{ANAMSO}^{7}$ and $\mathrm{UFS}^{8}$ in April 2014, which applies to seed production especially on sunflower and rapeseed.

In addition, following a recommendation from ANSES $\left(2014^{9}\right)$, giving advice for pesticide application during crop flowering, a draft revision of the decree of 28 November 2003 was submitted to the agricultural profession for opinion. Given the constraints that would have resulted from the modification of the 2003 decree, under the aegis of the FNSEA, all the sectors of field crops concerned by bee issues and pesticide application during crop flowering have finalized a series of sheets describing good practices to apply treatments on crops during flowering period in order to protect bees.

These sheets valued the ANSES recommendations as well as the work carried out by Terres Inovia $\left(\mathrm{CETIOM}^{10}\right.$ at the time) on bees foraging behavior throughout the day during the flowering period of the rapeseed crops and were submitted for approval to ITSAP. They cover the following crops: lavender and lavandin, industrial vegetables, vine, straw cereals, maize, apple and pear, potato, rapeseed, sunflower, protein peas and faba bean. All these good practices sheets are actively disseminated to producers by people involved in the sector, as well as by FDSEAs in the regions.

The main measure introduced in these sheets concerns the time of treatment of the crops, which was systematically positioned within three hours after sunset in the general case, or even within three hours before sunset under climatic conditions unfavorable to honeybee foraging activity. This activity is reduced when temperature is below $12^{\circ} \mathrm{C}$, which may occur during oilseed rape flowering.

This action, which involved all stakeholders in the agricultural sectors concerned, was brought to the attention of the Ministry of Agriculture, which considered it preferable to maintain the 2003 decree and not to follow up its proposed amendment.

Finally, the cultivation of faba beans was subjected to repeated flowering treatments for the control of the faba beetle which is essential for a valorization in human food. As it is the most remunerative for producers, it has allowed the development of the faba culture in the North of France. Due to the potential risk to bees and pollinators of this struggle, an indepth modification of practices has been proposed. Given that the beetle does not affect the yield of the crop or little, but that it degrades the quality of the seeds produced and renders them unfit for human consumption, the revision consisted of reserving production for a valuation in food only on the most favorable sectors less affected by the beetle. It would then allow to greatly limit the flowering treatments and to discourage them everywhere else by aiming solely at a valorization in animal feed. As the latter is insufficiently valued, the oil and protein crops inter-profession has initiated research programs aiming at identifying new outlets with higher added value in the medium term.

\section{Conclusion}

This last decade has made it possible to establish a dialogue between the world of professional beekeepers and farmers, which remains to be strengthen. This is the only reasonable way to reconcile the constraints and interests of the two parties, which need each other to function properly. Beekeepers need a favorable landscape context for their activity and this is the result of agricultural activity. For their cultivation, farmers often need the activity of pollinators and, in particular, bees to optimize the yield and quality of their harvest, particularly in seed or fruit production. More global solutions than the simple modification of crop protection practices will have to be sought to solve the problems found in the French beekeeping sector.

\section{Supplementary Material}

French version.

The Supplementary Material is available at https://www.ocljournal.org/10.1051/ocl/2017045/olm.

\section{References}

Henry M, Cerrutti N, Aupinel P, et al. 2015. Reconciling laboratory and field assessments of neonicotinoid toxicity to honeybees. Proc R Soc B. DOI: 10.1098/rspb.2015.2110.

MAAF (Ministère de l'Agriculture, de l'Agroalimentaire et de la Forêt), février 2013. Plan de développement durable de l'apiculture. Disponible sur http://agriculture.gouv.fr/sites/mina gri/files/pddapiculture_vf.pdf.

Cite this article as: Lagarde F. 2017. The measures implemented to reduce the impact of plant protection products on pollinators in France. OCL 24(6): D606.

\footnotetext{
${ }^{5}$ ADA France is the national federation of the regional associations for the development of apiculture

${ }^{6}$ Groupement National Interprofessionnel des Semences et Plants

${ }^{7}$ Association Nationale des Agriculteurs Multiplicateurs de Semences Oléagineuses

${ }^{8}$ Union Française des Semenciers

${ }^{9} \mathrm{https}$ ://www.anses.fr/fr/system/files/PHYTO2013sa0234.pdf

${ }^{10}$ Centre Technique Interprofessionnel des Oléagineux Métropolitains
} 